\title{
Forum
}

\section{Pedagogisch gezag is geen epistemisch gezag. Een pleidooi tegen de verwetenschappelijking van de pedagogiek}

\author{
Jan Bransen
}

PED 36 (2): 175-198

DOI: 10.5117/PED2016.2.BRAN

\begin{abstract}
Pedagogical authority is not a matter of epistemic authority. Against the scientification of pedagogy

I argue in this paper that upbringing and education do not profit from having become objects of scientific investigation. Epistemic authority, the typical kind of product of the sciences, has not much of a role to play in pedagogical relationships. This is mainly because such relationships are predominantly arranged around what I call 'normative expectations'. Such expectations are not grounded in knowledge of causal or instrumental patterns but are determined in a practice of mutually ascribing and undertaking obligations and entitlements. Epistemic authority would have to be based on a model of such practices, but using this kind of knowledge-based authority in such practices does disturb the practice due to looping effects. As a result of such looping effects pedagogical relationships are, from a scientific point of view, essentially moving targets. This does not mean that upbringing and education do not need serious intellectual attention. They do. But such attention should be grounded in common sense, rather than in a scientistic attempt to replace common sense.
\end{abstract}

Keywords: authority, scientification, pedagogical relationship, normative expectation, common sense 


\section{Inleiding}

Pedagogiek is een vreemde eend in de universitaire bijt. De term is ontleend aan het Grieks en verwijst naar het gidsen van kinderen; niet echt een activiteit die je aan een universiteit verwacht. Dat is echter niet de strekking van mijn betoog, want ik zou hartstochtelijk willen bepleiten dat zowel dat 'gidsen' als die 'kinderen' een ereplaats verdienen op het universitaire toneel. Dat toneel wordt vandaag de dag echter onterecht en eenzijdig gedomineerd door strikt epistemische pretenties, een dominantie die mij een doorn in het oog is. Mijn betoog voor de stelling dat het in de pedagogiek niet om epistemisch gezag behoort te gaan, moet dan ook begrepen worden tegen de achtergrond van een kritische bezorgdheid over de intellectuele verarming die zich in de universitaire wereld aan het voltrekken is.

Honderden jaren lang heeft de universiteit zich kunnen profileren als een institutie die onze beschaving vertegenwoordigt, een institutie die een cultuur behartigt waarin het om verwondering gaat, om verantwoordelijkheid, tolerantie, vrijheid en idealisme, en om het vertrouwen in een betere wereld. Dit ideaalbeeld werd natuurlijk aan iedere concrete universiteit vertroebeld door plaatselijke machtsverhoudingen en onhebbelijke bestuurders, maar dat neemt niet weg dat het ideaalbeeld fier verdedigd werd. De universiteit was daardoor bij uitstek een institutie waarin de moderne wetenschap geboren kon worden, een institutie waarin het slechts om zuiver epistemisch gezag behoorde te gaan, een vrijplaats voor onderzoekende geesten, voor hen die zich ingenieus, onvermoeibaar en systematisch inspannen om het hele universum adequaat en accuraat in kaart te brengen. Daarmee was de universiteit in één keer ook een institutie waarin het kritische denken floreerde, een institutie waarin beseft werd dat het uiteindelijk draait om wat we niet, of nog niet, weten, een institutie waarin het stellen van een vraag, welke vraag dan ook, daarom principieel waardevol is. In die institutie verdient de pedagogiek een ereplaats, zoals dat ook het geval was in de eerste Academie, vierhonderd jaar voor Christus, in Athene.

De hedendaagse universiteit is echter een ander verhaal. Het is een kennisfabriek geworden, een bedrijf waar antwoorden worden geproduceerd en epistemisch gezag wordt verhandeld, en eigenlijk niet eens meer in de vorm van mensen die dat gezag hébben, wetenschappers die iets begrijpen en hun inzichten kunnen uitleggen en toepassen. Epistemisch gezag is anoniem geworden, is geen eigenschap meer van mensen maar van modellen, theoretische, objectieve modellen die geïmplementeerd 
kunnen worden in een steeds beter beheersbare wereld. Tenminste, dat laatste moeten we dan maar geloven, en niet omdat het fier verdedigd wordt, maar omdat universiteiten steeds grotere marketingbudgetten hebben, en zich van nudges bedienen, en van persuasive communication, als ik me wat retoriek mag veroorloven. Los van deze nudges lijkt de disciplinering overigens al geslaagd: de meeste wetenschappers - en ook de pedagogen onder hen - lijken ervan overtuigd dat het aan een universiteit slechts om zuiver epistemisch gezag zou moeten gaan, en wel om gezag dat principieel onpersoonlijk is, een kwestie van feitelijke en objectieve kennis, en van theoretische modellen die met behulp van die kennis gebouwd kunnen worden. Die overtuiging kan zo hier en daar in sommige wetenschappen waardevol zijn, maar ze is, zoals ik in dit artijkel zal betogen, funest voor de pedagogiek.

Ik zal mijn betoog bouwen op een vijftal onderliggende inzichten $(\$ 1-5)$. Vervolgens zal ik ingaan op wat ik beschouw als een historische vergissing, de poging pedagogiek te beschouwen als een handelingswetenschap ( $\$ 6)$, zal kort iets zeggen over het hart van de pedagogiek, de opvoedingssituatie (§7), waarna ik zal betogen dat zuiver epistemische ambities voor de pedagogiek tot zelfbedrog leiden en pedagogiek zich dus niet als een empirische wetenschap zou moeten willen begrijpen (\$8-10). Dat opent de ruimte voor het appreciëren van pedagogisch gezag als, precies, pedagogisch gezag (§11).

\section{Gesitueerde cognitie}

Eén van de mooiere ontdekkingen die goed tot ons begint door te dringen vanuit de hedendaagse cognitiewetenschap is het besef dat kennis een natuurproduct is. Lang hebben we in de Westerse cultuur geleefd met een sterk besef van een cruciaal onderscheid tussen enerzijds ons lichaam en anderzijds onze geest, waarbij die geest op allerlei manieren buiten of tegenover de natuur werd gedacht en zich bezighield met het transcendente, het abstracte, het logische, het rationele, het symbolische. Die onfortuinlijke tegenstelling zijn we langzaam kwijtgeraakt, in het voetspoor van o.a. Darwin, Ryle en Varela (Richards, 1987; Ryle, 1949; Shapiro, 2011; Varela, Thompson, \& Rosch, 1991) Cognitie is een biologisch vermogen dat een belangrijke functie vervult: ze stelt ons in staat om de camouflages te ontmaskeren waar de natuur zich veelvuldig van bedient. Prooi- en roofdieren doen zich op allerlei manieren anders voor dan ze zijn, en de kracht van onze cognitieve vermogens is onder andere gelegen in het feit dat wij 
schijn van werkelijkheid kunnen scheiden. Daarnaast heeft ook ons planvermogen, onze praktische rationaliteit, zich vanuit onze biologie ontwikkeld.

Deze nieuwe duiding van cognitie heeft geleid tot een nieuw paradigma voor de cognitiewetenschap, een paradigma dat gestaag aan invloed wint. Er is een hele reeks Engelse bijvoeglijk naamwoorden die in stelling worden gebracht om dit paradigma te karakteriseren. Kennis is embodied, embedded, extended, situated, enactive. Het is hier niet de plaats dit paradigma kritisch uiteen te zetten. Ik doe hier simpel alsof het zijn toonaangevende plaats al ingenomen heeft en zal onderzoeken wat dit betekent voor de academische pedagogiek.

Dit nieuwe paradigma dwingt ons te beseffen dat kennis zich daar bevindt waar mensen hun activiteiten ontplooien. Kennis ligt niet opgeslagen in een bibliotheek en is geen kwestie van het weet hebben van abstracte theoretische principes. Kennis is primair een kwestie van know how, niet van know that (Ryle, 1945) Dat betekent nogal wat voor de universiteit, en vooral voor de academische pedagogiek zoals die zich in Nederland ontwikkeld heeft. Want als kennis vooral een kwestie van intelligent en goed geïnformeerd handelen is, en niet van abstract theoretiseren, wat doen pedagogen dan aan een universiteit? Ik wil niet suggereren dat al dat getheoretiseer nergens goed voor is. Maar we moeten misschien wel de conclusie trekken dat de scientist-practitioner werkelijk de ideaaltypische pedagoog zal moeten zijn. Daarbij moet benadrukt worden dat nog lang niet duidelijk is hoe we voor elkaar zullen kunnen krijgen dat het koppelteken tussen 'scientist' en 'practitioner' ophoudt vooral te functioneren als scheidingsteken. Er zal met andere woorden een einde moeten komen aan het voortbestaan van twee grondig gescheiden praktijken, een theoretische die zich in de academische wereld afspeelt, en een praktische die zich in scholen, instellingen, praktijkruimtes en (vervangende) huiskamers afspeelt. Als kennis embodied, embedded, extended, situated en enactive is, dan is de scheiding tussen universiteit en samenleving ongepast, ook voor wetenschappelijke kennis.

\section{Respons-afhankelijke begrippen}

Begrippen als DOM, BRUTAAL en VLIJTIG vertellen altijd ook iets over de gebruikers, en dat blijft zo, zelfs als we ze in de werkelijkheid zouden kunnen verankeren met behulp van gevalideerde meetinstrumenten. Deze begrippen heten 'respons-afhankelijk' en ik zal in dit artikel het gelijk 
accepteren van de filosofen die verdedigen dat alle begrippen responsafhankelijk zijn, ook de begrippen die een hoofdrol spelen in de wetenschap. ${ }^{1}$ Een belangrijke consequentie van deze stellingname is dat we in iedere kennisaanspraak impliciet twee aannamen doen: dat degenen die de aanspraak doen en erkennen over een normaal taalvermogen beschikken en dat de zaak waarover gesproken wordt in gunstige omstandigheden onderzocht is. Om dit concreet te maken: als jij mij vertelt dat Geert dom is en Khadija vlijtig, en ik geloof jou, dan vooronderstel ik dat onze beheersing van de Nederlandse taal normaal is en dat jij in gunstige omstandigheden hebt kunnen vaststellen dat Geert dom is en Kadija vlijtig. Je hebt bijvoorbeeld de beschikking over een IQ-test van Geert die correct afgenomen is en die, zeg, een score van 69 heeft opgeleverd. En je hebt bijvoorbeeld al vaak kunnen constateren dat Khadija altijd als eerste klaar is met haar huiswerk. Natuurlijk zijn dit normatieve aannamen, en de implicatie van mijn stellingname is dat dergelijke aannamen achter alle kennisaanspraken liggen, ook achter scheikundige uitspraken als "Het kookpunt van alcohol is $78^{\circ} \mathrm{C}$." en pedagogische uitspraken als "Onveilige hechting verhoogt het risico op leerproblemen." Deze respons-afhankelijkheid benadrukken wijst op de plicht die impliciet altijd verscholen ligt in iedere kennisaanspraak; namelijk, dat er een normatieve verantwoording gegeven moet kunnen worden van de methodologie én het conceptuele kader dat gebruikt is om tot de kennisaanspraak te kunnen komen. Ik wijs graag op die plicht met behulp van alledaagse woorden die gerechtvaardigde vragen oproepen. Wat impliceren we als we vooronderstellen dat het taalvermogen van de betrokkenen normaal ontwikkeld is? En wat impliceren we als we aannemen dat de spreker het besproken object in gunstige omstandigheden heeft kunnen bestuderen? Die vragen zijn niet retorisch bedoeld. Ik wil geenszins veronderstellen dat die aannamen altijd dubieus zijn. Maar ze verdienen wel altijd aandacht en expliciete onderbouwing.

\section{Continuïteitsthese}

Voor Quine, toch een grote voorvechter van het belang van de groei van wetenschappelijke kennis, staan wetenschap en gezond verstand niet tegenover elkaar maar in elkaars verlengde (Quine, 1992) Gezond verstand is onze alledaagse rationaliteit die sinds de Verlichting tegenover politieke willekeur en religieus bijgeloof staat, en die daarin de wetenschap altijd aan haar zijde heeft gevonden, als een betrouwbare, meer systematische en zorgvuldigere bondgenoot van ons alledaagse weten. Ik verdedig deze con- 
tinuïteit tussen gezond verstand en wetenschap. Dat impliceert een breuk met wat een gewoonte lijkt te zijn geworden in de moderne gedragswetenschap - namelijk de gewoonte te denken dat gezond verstand een poel van irrationele, sentimentele en chauvinistische vooringenomenheid zou zijn, een kwestie van ongefundeerde intuïties die drastisch gecorrigeerd moeten worden door wetenschappelijk verantwoorde deskundigheid. Ik hou deze gewoonte zelf voor een bias, een overcorrectie van sociale wetenschappers die binnen de academie zo graag serieus genomen willen worden.

De bias vindt overigens ook grond in een verwarring die in het Engelse taalgebied heeft kunnen ontstaan omtrent de referent van de term "folk psychology" (Baker, 1999) Deze term verwijst naar de vermogens die mensen inzetten om met elkaar samen te leven, maar soms lijkt het alsof de term niet verwijst naar deze vermogens, maar naar het quasi-theoretische product van deze vermogens, alsof het niet om know how gaat, maar om know that. Gezond verstand verschijnt dan als een prototheorie die door de gedragswetenschap weerlegd moet worden, zoals ooit het geocentrische wereldbeeld weerlegd moest worden door Copernicus' heliocentrische theorie. Dezelfde verwarring treffen we overigens soms ook aan als "wetenschap" gebruikt wordt om te verwijzen naar het totaal van geaccumuleerde wetenschappelijke kennis, alsof wetenschap zelf een theory of everything is, en niet de menselijke praktijk die zo'n theorie nastreeft.

De continuïteitsthese die ik in dit artikel vooronderstel heeft betrekking op de continuïteit tussen enerzijds ons alledaagse gezonde verstand als een verzameling vermogens en anderzijds de wetenschappelijke praktijk waarin we die vermogens kritisch, zorgvuldig en systematisch proberen te perfectioneren.

\section{Meervoudigheidsthese}

Ons alledaagse gezonde verstand, zo vooronderstel ik vervolgens, vormt geen geünificeerd geheel. ${ }^{2}$ Daar heeft niemand last van, omdat niemand in de praktijk behoefte heeft aan één omvattend geheel aan kennis. Totale consistentie en coherentie zijn theoretische desiderata die niet thuishoren bij kennis opgevat als natuurproduct. Als we letten op de verwachtingen die wij dankzij ons gezonde verstand hebben van wat zich in concrete scenario's zal kunnen voordoen, en onze kennisaanspraken even laten voor wat ze zijn, dan zullen we ontdekken dat we in de praktijk voortdurend gebruik maken van drie verschillende soorten verwachtingen. Deze soorten zijn niet gemakkelijk tot elkaar te herleiden. In theorie doet dat 
misschien wat ongemakkelijk aan, maar in de praktijk is dit geen enkel probleem, en zou een reductie zelfs ongewenst zijn.

Soms hebben onze verwachtingen een oorzaak-gevolg karakter. Als wij met fysische dingen omgaan (en ook menselijke lichamen zijn fysische dingen) dan laten onze verwachtingen een inzicht in causale relaties zien. Iemand die uitglijdt, zal vallen. Een biljartbal die tegen een andere geketst wordt, zal die andere bal in beweging brengen. Causale verwachtingen kunnen als voorspellingen geformuleerd worden, en hoe beter je theorie, hoe beter je voorspellingen.

Als we met de levende natuur omgaan, hebben onze verwachtingen een ander karakter, een doel-middel karakter. Ze laten dan ook inzicht in een ander type relatie zien: instrumentele relaties. Een muis rent weg voor een kat, terwijl een kat juist naar een muis toeloopt. Beiden willen overleven, maar de muis heeft voor dat doel andere middelen nodig dan de kat. De mechanisering van het wereldbeeld heeft ons laten zien dat heel veel (misschien wel álle) uitspraken over instrumentele relaties gereduceerd kunnen worden tot uitspraken over causale relaties. Dat wil echter niet zeggen dat al onze doel-middel verwachtingen herleid kunnen worden tot oorzaak-gevolg verwachtingen. Doel-middel verwachtingen hebben een ingebouwde rationaliteit die we niet aantreffen in oorzaak-gevolg verwachtingen (Dennett, 1987)

Als we met andere mensen omgaan, worden onze verwachtingen door nog weer een heel ander karakter gekenmerkt, een normatief karakter. Hier gaat het niet om doelen en middelen of om oorzaken en gevolgen, maar om verplichtingen en bevoegdheden. Als ik met iemand een afspraak heb gemaakt, dan verwacht ik dat hij ${ }^{3}$ op het afgesproken tijdstip op de afgesproken plek is. Dat is geen kwestie van causaliteit en ook geen kwestie van instrumentaliteit, maar een kwestie van normativiteit. Ik heb de bevoegdheid hem daar te verwachten, omdat hij de verplichting heeft daar te verschijnen. Omgekeerd heeft hij een vergelijkbare bevoegdheid en ik een vergelijkbare verplichting. Bevoegdheden en verplichtingen structureren onze sociale werkelijkheid op een buitengewoon complexe, gedetailleerde, subtiele en impliciete wijze. Deze tekst, bijvoorbeeld, kan ik alleen maar schrijven tegen de achtergrond van een veelvoud aan normatieve verwachtingen die wij (lezer en schrijver) ten opzichte van elkaar hebben en bij voortduring impliciet bekrachtigen. Het bijzondere van normatieve verwachtingen is dat de verantwoordelijkheid voor het uitkomen van die verwachtingen principieel gedistribueerd is, gedeeld wordt door alle betrokkenen. Daarin verschillen deze verwachtingen op een significante manier van de andere twee. Als een biljartbal anders beweegt dan ik verwacht, 
dan ben ik, en alleen ik, verantwoordelijk voor de onjuistheid waarop mijn verwachting gebaseerd is. Had ik mijn bronnen maar beter moeten checken. Maar als ik een afspraak misloop, omdat jij niet bent waar ik jou verwacht, dan is het nooit zo dat ik, en alleen ik, daar verantwoordelijk voor ben. Natuurlijk, ik kan het fout onthouden hebben, maar voor het slagen van onze afspraak kan het nooit voldoende zijn dat ik het goed onthoud en dat ik me aan de afspraak houd. Jij moet dat ook doen. Jij draagt principieel medeverantwoordelijkheid voor het uitkomen van mijn verwachtingen. En omgekeerd.

Ik kan hier niet verder op deze onderscheidingen ingaan, maar zal het sui generis karakter van deze drie typen verwachtingen in dit artikel vooronderstellen.

\section{Alledaags reflectievermogen}

Een even vanzelfsprekend als belangrijk onderdeel van ons gezonde verstand is ons alledaagse reflectievermogen. Dit vermogen staat ons toe en moedigt ons aan de onderzoekende houding aan te nemen op het moment dat onze onmiddellijke verwachtingen niet uitkomen. We kunnen dit zo complex en zo lichtvoetig als we willen conceptualiseren, maar de praktische tweedeling tussen enerzijds 'de automatische piloot' en anderzijds 'de onderzoekende houding' is kenmerkend genoeg voor de met rede begiftigde dieren die wij zijn. ${ }^{4} \mathrm{Wij}$ hebben in ieder scenario onmiddellijk verwachtingen, of we nu als baby in de wieg liggen en nog geen enkele gearticuleerde verwachting hebben of als experimenteel fysicus met meer dan duizend collega's van over de hele wereld honderden controles uitvoeren om er zeker van te kunnen zijn dat we in onze data overtuigend bewijs aantreffen voor het bestaan van zwaartekrachtgolven (Abbott, 2016) En zolang die onmiddellijke verwachtingen niet gefrustreerd worden, bouwen we - als het ware gedachteloos en in 'flow' - op hen voort, ook al blijkt dat soms minder verstandig dan het leek, als wij bijvoorbeeld op weg naar de foyer achter anderen aanlopen en onbedoeld in de kelder van de schouwburg terechtkomen.

Maar zodra onze verwachtingen niet uitkomen, schakelen we over op de onderzoekende houding. Vanuit die houding onderzoeken we de kwaliteit van onze verwachtingen en voor zover die een oorzaak-gevolg of een doel-middel karakter hebben, concentreert onze aandacht zich op het epistemische gezag dat wij met betrekking tot de zaak in kwestie nodig hebben om betrouwbare verwachtingen te kunnen ontwikkelen. Klopt onze 
kennis van de causale relaties tussen de dingen waar wij in dit scenario mee te maken hebben? En klopt onze kennis van de instrumentele relaties? Met betrekking tot deze twee typen verwachtingen is wetenschappelijke zorgvuldigheid een uitstekende versterking van het gezag dat wij met onze onderzoekende houding beogen te bewerkstellingen. De kritische rationaliteit die Popper aanwees als het hart van de moderne wetenschap is kenmerkend voor onze onderzoekende houding, maar is als een lokaal, gesitueerd en persoonlijk vermogen van op zichzelf staande individuen natuurlijk lang zo krachtig niet als het epistemische gezag dat wij met zijn allen hebben weten te realiseren in de systematische, gecontroleerde en methodische praktijk van het wetenschappelijk onderzoek. ${ }^{5}$

Maar als onze normatieve verwachtingen gefrustreerd worden, vraagt de onderzoekende houding van ons een ander soort respons. Als het om normatieve verwachtingen gaat, gaat het immers niet alleen maar om kennis, gaat het niet om de kwaliteit van onze voorspellingen, maar gaat het om onze wederzijdse afstemming, en in geval van frustratie dus om wederzijds onbegrip. Natuurlijk kan dat aan mij liggen, aan mijn beperkte sociale intelligentie, mijn culturele achterstand, of aan mijn vooroordelen, mijn vooringenomenheden, of mijn onvermogen relevante informatie op te doen en correct te verwerken over wat jou beweegt. Maar het kan ook aan jou liggen, op overeenkomstige manieren. Waarschijnlijk ligt het overigens aan ons beiden, waarbij het natuurlijk helemaal niet zo interessant is, en vaak contraproductief, om energie te gaan steken in het onderzoeken van wiens fout het nu uiteindelijk is geweest. Dat is weliswaar een begrijpelijke reactie, maar ook typisch een moderne reactie, een reactie die stoelt op het ideaal van ultieme controleerbaarheid, op de droom van een autonoom subject dat in principe toegang heeft tot een absoluut perspectief.

Maar als het om de mislukte afstemming gaat van mijn verwachtingen (over jouw en mijn verplichtingen en bevoegdheden) op jouw verwachtingen (over mijn en jouw verplichtingen en bevoegdheden), dan gaat het om meer dan zuiver epistemisch gezag. Wat vanuit de onderzoekende houding nodig is als onze onmiddellijke normatieve verwachtingen niet blijken te werken, is een gezamenlijke verkenning van al onze al dan niet gedeelde vooronderstellingen. Dat is een verkenning van wat ieder van ons voor vanzelfsprekend heeft gehouden in zijn of haar leefwereld, bijvoorbeeld het vanzelfsprekende gegeven dat jij mijn leefwereld bent binnengekomen, terwijl jij vermoedelijk dacht dat ik jouw leefwereld ben binnengekomen. Het zal duidelijk zijn dat in een scenario waarin onze normatieve verwachtingen worden gefrustreerd, er een grote behoefte is aan gezag, waarbij het ongetwijfeld even duidelijk zal zijn dat dit geen ongecompliceerd epistem- 
isch gezag zal kunnen zijn. Het zal waarschijnlijk zelfs helemaal geen ongecompliceerd gezag kunnen zijn. Juist dat gezag wordt immers gemist, en betwist, ook dat.

Het is precies op dit punt dat de behoefte aan pedagogisch gezag zich laat voelen. Want wie gaat wie opvoeden? En op grond waarvan? En waartoe?

\section{Handelingswetenschap}

$\mathrm{Al}$ sinds Plato associëren wij gezag met het theoretische perspectief dat onbetrokken, neutraal en objectief is. Wie met de voeten in de modder staat, ingeperkt door de urgentie van de praktijk en in de ban van zijn eigen onmiddellijke neigingen, verzet misschien wel veel goed werk, maar mist, zo denken wij, ook de benodigde afstand om weloverwogen te kunnen beoordelen of hij goed bezig is, of die urgente problemen de aandacht waard zijn, en of die onmiddellijke neigingen verstandig zijn. De onderzoekende houding die wij wel in móeten nemen als onze verwachtingen niet uitkomen, is een houding, zo denken wij, die we ook permanent zouden kunnen innemen en die ons dan een permanent gezag zou kunnen verlenen. Zo'n soort redenering gaat schuil achter de figuur van de moderne intellectueel, die een vrijgestelde theoreticus is en in het voetspoor van Huygens, Newton en Einstein epistemisch gezag kan verwerven, maar ook in het voetspoor van Spinoza, Kant en Sartre moreel gezag.

Het is deze figuur, maar meer nog de achterliggende redenering, die in de tweede helft van de vorige eeuw geleid heeft tot de opkomst, en het verval, van de theoretische pedagoog, de wetenschapper die zichzelf als handelingswetenschapper heeft geprobeerd te definiëren. ${ }^{6}$ De pedagogiek, zo is het besef, is een bijzonder soort wetenschap, omdat het in het pedagogische domein niet slechts om het verwerven van epistemisch gezag gaat. Een pedagoog zal nooit denken dat hij klaar is als zijn intellectuele verlangen bevredigd is omdat hij een correct model van de pedagogische werkelijkheid heeft kunnen construeren. De pedagoog zal het altijd vooral ook gaan om wat er uit naam van zijn epistemisch gezag concreet in een problematische opvoedingssituatie gedaan kan worden om weer perspectief te zien en betekenis te ervaren. Deze woorden zijn van Wim ter Horst (Ter Horst, 1978, p. 22), die ik hier wil eren als een icoon van de Nederlandse pedagogiek, vooral ook omdat hij zo onophoudelijk geworsteld heeft met de afstand tussen theorie en praktijk die hij als wetenschapper - ook als menselijke planwetenschapper (Ter Horst, 1980, p. 18) - steeds 
weer zelf gecreëerd heeft. Typerend voor deze worsteling is een verzuchting als:

Zolang de pedagogiek als theorie nog niet is teruggekeerd op haar vertrekpunt de opvoedingssituatie - is haar taak niet volbracht. Dit heeft tot gevolg dat de uiteindelijke pedagogische uitspraken laag-bij-de-gronds en zelfs platvloers zijn. Iets dat niet altijd naar waarde wordt geschat. (Ter Horst, 1980, p. 106)

Hoewel pedagogische uitspraken hun alledaagse karakter nodig hebben om hun rol te kunnen spelen in het herstellen van het gewone leven, zoals Ter Horst (2006) dat noemt, dragen ze wel degelijk het gewicht van de theoretisch geïnformeerde wetenschapper. Deze wetenschappelijke pedagoog werkt met een theoretisch model dat hij ontwikkeld heeft door een steeds groter bereik voor zijn uitspraken te realiseren. Dat doet hij door steeds verder te abstraheren: via "de ervaringslaag, de vuistregellaag, de lagen van de bijzondere en de algemene strategieën en van de theorie in engere zin." (Ter Horst, 1973, p. 142)

Twee vragen doemen hier wat mij betreft toch tamelijk vanzelfsprekend op, vragen die voor de hand liggen als je het paradigma van de gesitueerde kennis accepteert, maar dus ook vragen die in de jaren tachtig van de vorige eeuw nog niet zo voor de hand lagen, omdat men toen gezag zowel epistemisch als moreel gezag - onmiddellijk associeerde met theoretische afstand. Daardoor was het toen vanzelfsprekend te denken dat gezag een kwestie van uitspraken was, van abstracte uitspraken met een groot bereik. Maar nu zijn dit precies de vragen: Waarom zou het gezag van een handelingswetenschap zich tonen in uitspraken? En waarom zou een groot bereik uitspraken meer gezag geven?

Ik zal deze vragen met een beetje een omtrekkende beweging proberen te beantwoorden. Ik heb de omweg nodig omdat ik een beter inzicht in de pedagogische relatie nodig heb om een scherpere kritiek te kunnen formuleren op de rol die theoretische afstand speelt in de wetenschappelijke ambitie van de pedagogiek.

\section{De opvoedingssituatie}

Mensen worden drie keer opgevoed, zo wil een tegeltjeswijsheid. En ik begin graag met deze tegeltjeswijsheid, omdat het object van de pedagogiek, ook als het een wetenschap zou zijn, zo geweldig alledaags is. Eerst worden we door onze ouders opgevoed, zo zegt ons dat tegeltje, dan door 
onze partner, en tenslotte door onze kinderen. De pedagogische relatie, die in opvoedingssituaties centraal staat, kan blijkbaar gemakkelijk op zijn kop gezet worden. Zij is een relatie van ogenschijnlijk eenzijdige beïnvloeding, waarbij de ene partij een blijvende gedragsverandering bij de andere partij wil bewerkstelligen. Wat kunnen we over opvoedingssituaties leren als we de tegeltjeswijsheid serieus nemen? Ik zal in omgekeerde volgorde werken, om redenen die wel duidelijk zullen worden.

1. Als je oud genoeg bent om getuige te zijn van de poging van jouw kinderen jou op te voeden, zul je ongetwijfeld tot de conclusie komen dat opvoeding vooral zelf-opvoeding is. Natuurlijk hebben anderen heel je leven al geprobeerd je te veranderen. Of je juist geprobeerd te beschermen tegen verandering. Mensen roepen elkaar voortdurend ter verantwoording, bevestigen elkaar of bekritiseren elkaar, en corrigeren elkaar omdat ze liever hebben dat de ander zich anders gedraagt en zich anders opstelt dan hij doet. En als je kinderen dan in volle overtuiging proberen jou andere gewoonten bij te brengen, en als je dat merkt, dat als zodanig merkt, dan is dat al gauw ongemakkelijk confronterend. Ze tegemoet komen betekent dan jezelf onderhanden nemen, betekent gaan sleutelen aan jouw gewoonten, betekent je afvragen waar je echt om geeft, wat je echt, met open ogen, kunt omarmen als jouw moeite waard.

2. Voordat het zover is dat je op commando van jouw kinderen je slechte gewoonten kritisch onder ogen probeert te zien, heb je al iets anders van je partner kunnen leren, iets dat gaat over principiële gelijkwaardigheid. Mensen verschillen. Mensen hebben verschillende vermogens, dragen verschillende verantwoordelijkheden, hebben verschillende verlangens en behoeften en ontwikkelen zich in een verschillend tempo. Maar in een relatie botten al die verschillen uit tot een bijzonder soort gelijkwaardigheid. Deze is geen kwestie van distributieve rechtvaardigheid, geen balans tussen kosten en baten, geen eindafrekening die jaarlijks in het emotionele huishoudboekje opgetekend kan worden. In een relatie is de wederzijdse opvoeding geen instrumentele inspanning, geen doelgericht middel om een bepaald doel te bereiken, ook al ziet het er vaak zo uit, wordt het vaak zo ervaren en ook vaak zo ondernomen. Maar liefde wil iets anders, ook in de opvoedingssituaties waar intieme partners elkaar geregeld in proberen te betrekken. Je probeert de ander te beïnvloeden, probeert hem te veranderen, maar zult hem vooral de ruimte moeten laten om zichzelf te kunnen blijven zijn (en dat betekent zichzelf te kunnen blijven ontwikkelen), ondanks, maar ook dankzij, de dynamiek die jullie verschil met zich meebrengt.

3. We kennen de pedagogische relatie natuurlijk vooral als een relatie 
tussen volwassenen en kinderen, waarbij de volwassenen vanzelfsprekend de opvoeders zijn en de kinderen de wezens die opgevoed worden. Die opgevoed moeten worden. Omdat hun zelfstandigheid nog niet ontwikkeld is waardoor de verantwoordelijkheid nu eenmaal asymmetrisch op de schouders van de volwassenen drukt. Juist omdat dit beeld van de pedagogische relatie zo stilzwijgend voor vanzelfsprekend wordt gehouden, juist omdat we bij opvoedingssituaties altijd onmiddellijk aan volwassenen en kinderen denken, ben ik aan de andere kant van die tegeltjeswijsheid begonnen. Daardoor heb ik op twee kenmerken van de opvoedingssituatie kunnen wijzen die we gemakkelijk over het hoofd zien als we zo onnadenkend beginnen met aandacht voor die typisch asymmetrische relatie tussen volwassenen en kinderen. Deze twee zijn:

- opvoeding is vooral zelf-opvoeding

- opvoeding is het helpen organiseren van ruimte voor eigenheid in een relatie die gekenmerkt wordt door dynamiek, verschil, afhankelijkheid en gelijkwaardigheid

Aan die kenmerken kunnen we er nu nog drie toevoegen, die wellicht vertrouwder klinken, maar die nu hopelijk in een wat ander perspectief verschijnen:

- opvoeding is het beïnvloeden van een ander om een blijvende gedragsverandering in die ander te bewerkstelligen

- opvoeding is gericht op het stimuleren van de ontwikkeling tot zelfstandig mens

- opvoeding is een verantwoordelijkheid die door de meest zelfstandige gedragen moet worden

Als dit in abstracto de vijf kenmerken zijn waaraan concrete interactieprocessen moeten voldoen om typerend te zijn voor de opvoedingssituatie, wat betekent dit dan voor de wetenschappelijke ambities van de pedagogiek?

\section{Monsters onder het bed}

De ambitie van de wetenschappelijke pedagogiek is ogenschijnlijk helder genoeg: zij wil een positieve bijdrage leveren aan de kwaliteit van opvoedingssituaties door wetenschappelijke kennis te verwerven van die opvoedingssituaties en deze wetenschappelijke kennis in te zetten in die opvoedingssituaties. Deze ambitie lijkt naadloos aan te sluiten bij het nieuwe 
paradigma van de gesitueerde kennis. Jouw kind van acht is bijvoorbeeld bang voor monsters onder zijn bed en je bent zijn jammerklachten inmiddels een beetje zat, hebt samen met hem al onder het bed gekeken, en niets gezien, hebt hem streng toegesproken, bent bij hem blijven zitten tot hij in slaap viel, maar wil dat niet blijven doen omdat het vermoeiend en tijdrovend is en je niet weet wat het effect op de lange termijn zal zijn, maar je weet ook niet goed wat je dan wel, of juist niet, anders zou kunnen doen. Trial and error lijkt een onverstandige optie, want je bent niet de eerste die in deze opvoedingssituatie terecht is gekomen, en error voorkom je liever, wat ook mogelijk moet zijn, gezien de ervaring die anderen inmiddels opgedaan moeten hebben. Hoe zou je die ervaring van anderen kunnen benutten? Zou het mogelijk kunnen zijn om die ervaring van anderen zodanig te systematiseren dat jij gewapend met een theorie als het ware op de schouders van reuzen gezeten precies weet wat jij in deze opvoedingssituatie met je kind en zijn angst voor monsters onder zijn bed moet doen?

Het is maar een voorbeeld, maar het is een gemakkelijk generaliseerbaar voorbeeld - je zou evengoed een ouder kunnen zijn van een klassieke autist, of een groepsleider van een wees uit Syrië, of een leerkracht van een extreem dromerig kind, of de begeleider van een verstandelijk beperkte adolescent, of de vrouw van een ziekelijk jaloerse man, of het volwassen kind van een depressieve moeder, of, ook dat nog, een toegewijde medewerker van een narcistische manager. In al die gevallen heb je behoefte aan kennis - van de situatie, van jezelf, maar beslist ook, en ogenschijnlijk vooral, van het kind, of de mens, wiens gedrag je zou willen veranderen, of wiens karakter je zou willen (her)vormen. Die kennis kan je vallend en opstaand opdoen, maar als al honderdduizenden (miljoenen?) kinderen van acht bang geweest zijn voor monsters onder hun bed, dan moet dat vallen en opstaan te voorkomen zijn. Zou je denken, toch? En idem dito voor je omgang met autisten, oorlogsslachtoffers, dromers, LVB'ers, narcisten, enzovoort, ook al zullen de aantallen misschien kleiner zijn.

Dit is het standaarduitgangspunt voor de wetenschappelijke pedagoog en hij heeft zich, aansluitend, twee vooronderstellingen eigen gemaakt. Ten eerste, het gaat volgens hem inderdaad om het bepalen van algemene generalisaties op basis van grote aantallen (Kroonenberg, 2002, p. 85) Ten tweede, het systematiseren van grote verzamelingen data vraagt om statistische methoden en technieken. ${ }^{7}$ En zo is het gekomen dat wetenschappelijke uitspraken opgevat worden als abstracte uitspraken, algemene proposities die uit de aard der zaak een groot bereik hebben. Dit wordt vandaag de dag nauwelijks ter discussie gesteld ${ }^{8}$, wordt vaak volstrekt evident ge- 
acht, soms zelfs per definitie waar geacht, alsof het een tautologie betreft (Ter Horst, 1980, p. 20-35)

Er kleven voor de pedagogiek echter drie nadelen aan de gemeenplaats dat algemene uitspraken met een groot bereik typerend zijn voor de kennis van de pedagogische relatie waar behoefte aan is. Op de eerste plaats zijn er enorme inductieproblemen. Er zijn ongetwijfeld al heel veel kinderen van acht bang geweest voor monsters onder hun bed, maar geen van die kinderen heeft in het bed van mijn zoon geslapen, en geen van die kinderen was mijn kind, en geen van die kinderen was vandaag voor het eerst bang voor monsters onder zijn bed, vandaag, 18 maart 2016, de dag waarop mijn kind een foto in de krant zag staan van een gans die door de voorruit van een bestelbusje is gevlogen, precies zo'n busje als mijn buurman heeft. Ik neem aan dat ik niet door hoef te gaan om het punt duidelijk te maken. Aan de productiekant van algemene, wetenschappelijk verantwoorde uitspraken moet er heel veel gebeuren, en vooral heel veel als wezenlijk onproblematisch voorondersteld worden, wil er überhaupt sprake kunnen zijn van pedagogische theorievorming.

Aan de toepassingskant zijn de problemen minstens even groot, en inderdaad op een bepaalde manier complementair. ${ }^{9}$ Want stel dat een wetenschappelijk pedagoog mij tegemoet komt met een algemene, wetenschappelijk verantwoorde uitspraak, bijvoorbeeld dat knuffels kunnen helpen, maar minder goed dan de steun van ouders, die op hun beurt weer minder goed helpen dan 'zelfcontrole' (Mooney, Graziano, \& Katz, 1985), dan zal ik daar een hele kluif aan hebben voordat ik dit inzicht kan vertalen naar een effectief toepasbare interventie. En los daarvan is de kans natuurlijk best groot dat ik ook zelf wel op het idee kom om Gak, de lievelingsknuffel van mijn zoon, voorlopig liever even te verstoppen. Maar dan niet onder zijn bed, natuurlijk.

Het derde nadeel is echter veel belangrijker, en veel fundamenteler dan bovengenoemde methodologische problemen. De objecten van de pedagogiek, waar de beoogde wetenschappelijke uitspraken over zullen moeten gaan, zijn opvoedingssituaties, situaties waarin mensen een pedagogische relatie met elkaar hebben. In zo'n relatie spelen altijd ook normatieve verwachtingen mee, verwachtingen die, zoals ik in paragraaf 5 beschreven heb, een kwestie zijn van aan elkaar en aan zichzelf toegeschreven bevoegdheden en verplichtingen. Kenmerkend aan deze verwachtingen is dat hun gerechtvaardigdheid geen feitelijke grond heeft maar een functie is van het samenspel van toegeschreven bevoegdheden en verplichtingen. Of dat samenspel gerealiseerd wordt, hangt enerzijds af van de mate waarin de betrokkenen er in slagen elkaar en zichzelf duidelijk te maken welke 
bevoegdheden en verplichtingen zij menen te hebben en anderzijds van de goede wil om aan elkaars verwachtingen te voldoen. Zo'n samenspel leent zich niet voor een abstraherende, generaliserende beschrijving. Zo'n samenspel is een bijzondere prestatie, keer op keer opnieuw, geen zaak die je kunt kennen door hem te scharen onder algemene uitspraken met een groot bereik.

\section{Wetenschappelijke ambities en pedagogisch zelfbedrog}

De ambitie van de wetenschappelijke pedagoog om door middel van empirische theorievorming een bijdrage te leveren aan de kwaliteit van opvoedingssituaties leidt tot een veelzeggende vorm van zelfbedrog. Dat zelfbedrog wordt voorbereid aan de productiekant van de theorievorming omdat de wetenschappelijke pedagoog voorbij moet gaan aan het gegeven dat er geen enkel helder model bestaat voor algemene uitspraken over de twee fundamentele menselijke vermogens die we nodig hebben als er normatieve verwachtingen in het spel zijn:

- ons vermogen elkaars misverstanden te ontdekken en op te klaren

- onze goede wil

Natuurlijk, er bestaan veel boeiende, veelal filosofische publicaties over deze vermogens (Davidson, 1973, 1985; Frankfurt, 2006; Williams, 1981; Wood, 2003; Velleman, 2009), maar die spreken elkaar allemaal tegen en impliceren vooral dat theorievorming over deze vermogens niet veel anders kan zijn dan het op gang houden van een gesprek over de conceptualiseringsvraagstukken waarvoor het denken over deze vermogens ons stelt.

Het ontwijken van deze vraagstukken door stevig in te zetten op het verzamelen van bevindingen wakkert het zelfbedrog aan de toepassingskant aan. Want wat gebeurt er als een pedagoog zijn wetenschappelijke kennis inbrengt in een opvoedingssituatie? Dan intervenieert hij in het samenspel van toegeschreven bevoegdheden en verplichtingen! Dat is niet alleen een kwestie van het inbrengen van zijn eigen normatieve verwachtingen (de verwachting, bijvoorbeeld, dat de betrokkenen naar zijn epistemische gezag zullen moeten en zullen willen luisteren). Het is tevens een kwestie van een niet door hem te controleren verstoring van dit samenspel van normatieve verwachtingen. Die verstoring is het gevolg van de onontkoombare regressus die ontstaat als de pedagoog gaat anticiperen op wat de betrokkenen zullen verwachten dat hij zal verwachten dat zij zullen verwachten dat hij zal verwachten, enzovoort. Dat is immers precies 
de pointe van een relatie die op normatieve verwachtingen is gebaseerd: de verantwoordelijkheid voor de afstemming van dergelijke verwachtingen op elkaar is principieel gedistribueerd. Je kunt het als pedagoog niet alleen!

En de betekenis hiervan voor de ambitie van de wetenschappelijke pedagoog is desastreus. Want als hij werkelijk meent dat de enige rechtvaardiging voor zijn interventie gelegen is in zijn epistemische autoriteit, dan bijt hij zichzelf noodzakelijkerwijs in de staart, en ondermijnt qualitate qua zijn interventie. Want die interventie zal hoe dan ook de normatieve verwachtingen tussen de betrokkenen veranderen, op een manier die de wetenschapper niet strikt op basis van zijn kennis van de opvoedingssituatie zal kunnen voorzien noch op zuiver epistemische gronden zal kunnen beïnvloeden. Dat heeft alles te maken met het gegeven dat de normatieve verwachtingen van de wetenschapper zelf een rol van betekenis in zijn interventie zullen spelen. Deze verwachtingen hebben betrekking op de bevoegdheden en verplichtingen die de wetenschapper zichzelf toeschrijft. En zo'n zelftoeschrijving is niet te begrijpen als een descriptieve uitspraak, maar is zelf intrinsiek een normatieve bijdrage aan de interactie in de opvoedingssituatie. $^{10}$

Als dat zo is, dan is de hele omweg via wetenschappelijk verantwoorde theorievorming echter niet alleen een nodeloze omweg, maar ook essentieel een kwestie van misleidend zelfbedrog. En dat zelfbedrog neemt kwalijke vormen aan als het ten overstaan van de betrokkenen in een opvoedingssituatie expliciet wordt ontkend zoals in een opmerking als deze:

De empirische pedagogiek is ook bescheiden in de zin dat zij aan pedagogen in de praktijk nooit zal voorschrijven hoe de opvoeding eruit moet zien. Dat bepalen die opvoeders, leerkrachten en hulpverleners zelf wel, op basis van hun eigen inzichten en ervaringen, en liefst na kennis te hebben genomen van de meest recente wetenschappelijke kennis. (Van IJzendoorn \& De Frankrijker, 2002, p. 14).

Als je goed naar dit citaat kijkt, dan zie je de tegenspraak levensgroot opdoemen. Hij wordt verbloemd doordat in de eerste zin de indruk wordt gewekt dat "de empirische pedagogiek" een actor is, een persoon van goede wil, iemand die niet wil voorschrijven hoe het hoort. Maar in de laatste zin wordt diezelfde empirische pedagogiek weergegeven alsof het een zaak betreft: "de meest recente wetenschappelijke kennis". Die kennis mag geraadpleegd worden waarna het zogenaamd volstrekt aan het oordeel van de opvoeders overgelaten wordt wat zij met die kennis doen. Alsof je op een verpakking van pasta schrijft dat de kooktijd 9 minuten bedraagt maar tevens ergens anders op die verpakking vermeldt dat het uiteraard vol- 
strekt aan het eigen oordeel van de consument overgelaten wordt hoelang hij die pasta wil koken. In strikte zin heeft de producent van pasta natuurlijk gelijk als hij onderkent dat hij met min of meer verstandige, verantwoordelijke, zelfstandige en vrije consumenten te maken heeft. Maar dat neemt natuurlijk niet weg dat zijn opmerking over die kooktijd van 9 minuten wel degelijk als een voorschrift bedoeld is.

Zoals we Ter Horst hebben zien worstelen met die hopeloze omweg via de theorie, zo zien wij hier Van IJzendoorn en De Frankrijker worstelen met die heilloze interpretatie van hun gezag als puur epistemisch. Het is de hoogste tijd dat de pedagogen zich het karakter van hun professie goed realiseren: pedagogiek is geen strikt epistemische onderneming!

\section{Pedagogiek is geen empirische wetenschap}

Laat ik mijn argumentatie recapituleren aan de hand van drie paradigmatische casussen. Ik ben vertrokken - ten eerste - vanuit de aanname dat kennis gesitueerd is, een kwestie van know how, van te weten hoe, bijvoorbeeld, jij het best om kunt gaan met je kind van acht jaar dat bang is voor monsters onder zijn bed. Abstraheren is in zo'n situatie geen kwestie van het formuleren van algemene uitspraken met een groot bereik, van het formuleren van een theorie, maar een kwestie van parallellen, verbanden en analogieën zien, van iets te ontdekken aan die situatie omdat je een verband ziet tussen die angst voor monsters en bijvoorbeeld leesproblemen of agressief, ontwrichtend en zelfbeschadigend gedrag. Voor het benoemen van wat zich in zulke situaties voordoet hebben we - ten tweede respons-afhankelijke begrippen nodig. Dat zijn begrippen die iets vertellen over de betreffende verschijnselen, maar ook iets over degenen die daarover willen, of moeten, spreken. Dat impliceert aannames over de normaliteit van het taalvermogen van deze sprekers en over de gunstige omstandigheden waarin zij zich moeten bevinden om betrouwbaar te kunnen spreken over, bijvoorbeeld, de dyslexie die aan die leesproblemen ten grondslag ligt. Dat kan een kwestie van arbeidsdeling zijn, van deskundigheid, en van gecontroleerde diagnostiek. Mij kun je bijvoorbeeld niet vertrouwen als het over dyslexie gaat, maar als ik de deskundige bij uitstek mag geloven, kan er eigenlijk niemand over een normaal taalvermogen beschikken met behulp waarvan er begrijpelijk over dyslexie gesproken kan worden, omdat er geen gunstige omstandigheden zijn waarin dyslexie zich als dyslexie kan laten zien (Hasselman, 2015).

Arbeidsdeling is overigens wel degelijk mogelijk tussen wetenschappers 
en leken, waarbij er - ten derde - sprake is van continuïteit. Over alle werkelijkheidsdomeinen kun je als leek wel iets zeggen, maar jouw taalvermogen zal in heel veel domeinen niet normaal genoemd kunnen worden en jouw waarnemingsomstandigheden niet gunstig. Je kunt ongetwijfeld goed onder het bed van jouw zoon kijken, eventueel met een zaklamp, en je zult vast een betrekkelijk normaal begrip van MONSTER hebben. Maar weet je wat je ziet en hoe je erover moet spreken als je in een Orthopedagogisch Behandelcentrum te maken krijgt met een jeugdige "bij wie sprake is van sterk gestoord gedrag (J-SGLVB) en complexe gezinsproblematiek"? (Huitink, Vermaes, Engels, Ament, \& Nadorp, 2014, p. 234) Je hebt als leek ongetwijfeld te weinig concrete ervaring met zulke jeugdigen en je begrippenapparaat zal veel te schamel zijn. Goed dus dat er mensen zijn die zich specialiseren. Maar specialiseren vraagt principieel ten vierde - om het ontwikkelen van verschillende soorten verwachtingen. In sommige domeinen worden onze verwachtingen vooral gevoed door oorzaak-gevolg relaties, in andere domeinen vooral door doel-middel relaties, en in nog weer andere domeinen vooral door wederzijds toegeschreven bevoegdheden en verplichtingen. Het goed onderscheiden van deze soorten verwachtingen is cruciaal voor het ontwikkelen van deskundigheid en het is bijvoorbeeld juist het ontbreken van voldoende helderheid over deze verschillende verwachtingen die het begrip DYSLEXIE parten speelt. Want wat voor verwachting heb je precies als je verwacht dat het toevoegen van visolie om het tekort in de myelinisatie van zenuwcellen op te heffen, de leesprestaties van het kind ten goede zal komen? (Hasselman, 2015, p. 13) Enig idee?

Je eigen verwachtingen begrijpen, daar komt deskundigheid uiteindelijk op neer. Dat vraagt niet alleen, en niet eens zo zeer, om specialisatie, maar vooral - ten vijfde - om het kritisch blijven gebruiken van je alledaagse reflectievermogen. Als je verwachtingen niet uitkomen, waar ligt dat dan aan? Wat kunnen we verwachten van de 'ambulantisering van de zorg' voor het pedagogisch leefklimaat van jeugdigen met LVB en ernstige gedragsproblematiek? (Huitink et al., 2014) En wat voor effect zal een helder antwoord op deze vraag hebben op de verwachtingen waarmee een behandelaar in een Orthopedagogisch Behandelcentrum een jeugdige uit de J-SGLVB groep zal moeten vertellen dat hij binnenkort toch weer in een pleeggezin geplaatst zal worden?

De ambitie van de pedagogiek, zo heb ik - ten zesde - betoogd, vraagt precies op dit punt om het erkennen van het eigen gezag als geen strikt epistemisch, maar juist een uitgesproken pedagogisch gezag. Het heeft nooit lekker geklonken, handelingswetenschap, maar "integratieve interventie- 
wetenschap" is uiteindelijk geen haar beter. De pedagoog die zijn gezag zuiver wil ontlenen aan de epistemische status van zijn theorie - de status van de algemene uitspraken met een groot bereik die hij ambieert te kunnen opstellen - zit zichzelf onmogelijk in de weg. Hij mengt zich in opvoedingssituaties die bestaan bij de gratie van een complex samenspel van normatieve verwachtingen. Zijn interventie is qualitate qua een normatieve bijdrage aan dat samenspel die als zodanig verantwoord moet worden, dat wil zeggen als een normatieve bijdrage, en die niet vermomd behoort te worden als een zuiver cognitieve afleiding uit een methodologisch verantwoorde, wetenschappelijke theorie. Die theorieën zijn er helemaal niet en de pedagoog heeft ze bovendien helemaal niet nodig. De pedagoog die een wetenschapper wil zijn doet aan zelfbedrog en verspilt precies het gezag dat hij nodig heeft. Dat is juist een pedagogisch, geen epistemisch gezag!

\section{Pedagogisch gezag}

Maar hoe komt die pedagoog dan aan zijn pedagogische gezag? Dat is een even moeilijke als makkelijke vraag, een vraag die geldt voor ieder gezag in iedere opvoedingssituatie. Dat is, zoals ik - ten zevende - heb betoogd, iedere situatie waarin mensen elkaar beïnvloeden door te proberen blijvende gedragsveranderingen bij de ander te bewerkstelligen. Eigenlijk betekent dat gewoon iedere situatie waarin mensen verwikkeld zijn in een samenspel van normatieve verwachtingen. Als ik met de kapper praat, of meepraat, over voetbal, de aantrekkende huizenmarkt en de nieuwe pizzeria verderop in het dorp, dan zijn wij verwikkeld in een interactie waarin wij elkaars en ons eigen gezag vooronderstellen, inzetten en bevestigen. Misschien wil de kapper niet meer dan dat ik geloof dat ik bij hem onder het mes een ontspannen en genoeglijke tijd heb. Misschien wil ík hem overtuigen van de kwaliteit van FC Utrecht, of van mijn compassie voor de middenstand in ons dorp. Ons gezag als babbelaars vergezelt ons tijdens die gesprekjes op een vanzelfsprekende manier. Dat hoeft niet. Ik zou me zorgen kunnen maken over mijn onvermogen deel te nemen aan de onontkoombare small talk. Ik zou beducht kunnen zijn voor de gespreksvaardigheid van de kapper, jaloers op zijn ervaring als babbelaar, of onverschillig en stil, zodat de kapper er ook snel genoeg het zwijgen toe doet. Misschien denk ik wel gemeen dat hij zoveel praat omdat hij meer vertrouwen in zijn gebabbel heeft dan in zijn geknip. En wie weet maakt de kapper zich oprecht zorgen over zijn professionele gezag, over zijn kapperskwaliteiten. 
Gezag kun je krijgen, verdienen, opeisen, of nemen. Daar zijn geen vaste regels of procedures voor. Gezag is een buitengewoon glibberige en bij uitstek relationele eigenschap. (Bransen, 2011) Maar gezag, anders dan reputatie, is altijd een gesitueerde eigenschap, een eigenschap die zich keer op keer in concrete opvoedingssituaties realiseert. En of je het gezag waard bent dat je neemt, merk je wel aan het gezag dat je krijgt. Dat is een kwestie van ervaring, in de praktijk.

Die praktijk is voor pedagogen veelvoudig en heel ongelijksoortig. De wetenschappelijke pedagoog heeft het daarbij moeilijker dan de scientistpractitioners omdat hij aan de universiteit in allerlei achterhoedegevechten verzandt. Hij wordt door de psychologen namelijk niet voor vol aangezien, hoe vooraanstaand zijn publicaties ook zijn. En samen met de psychologen (in een precair en onbehaaglijk verbond) moet hij lijdzaam toezien hoe zij het als gedragswetenschappers afleggen tegen de biologen en de fysici, die op hun beurt weer om het grote geld moeten vechten met de neurowetenschappers en de medici. In die slangenkuil komt een pedagoog niet ver, ook al is zijn pedagogische gezag in de wandelgangen en op recepties onomstreden.

Daar, in dat concrete contact, is de pedagoog op zijn best. En als hij oud genoeg is kan hem de onbekommerdheid toevallen die Wim ter Horst laat zien in zijn prachtige boekje Het herstel van het gewone leven (Ter Horst, 2006) Dat is het boekje van een echte pedagoog, van een schrijver die veel pedagogisch gezag verdient, en die zich in een tijdsgewricht waarin dat maatschappelijk en intellectueel nog helemaal niet op waarde werd geschat, volkomen had bevrijd van de dwang wetenschappelijk mee te tellen.

Want het gaat niet om wetenschap, niet om epistemisch gezag. Het gaat in de pedagogiek om het gezamenlijk organiseren van ruimte voor de eigenheid van verantwoordelijke maar ook afhankelijke mensen in relaties die gekenmerkt worden door dynamiek, verschil, gelijkwaardigheid, misverstand en zelfbedrog.

En onze wetenschappelijke ambitie? Die is een monster. Onder ons bed. ${ }^{11}$

\section{Noten}

1. Denk aan o.a. Wittgenstein, Berkeley, Kant, Kuhn. Zie Bransen (2013, pp. 175-197). Zie ook Pettit (1991), Goldberg (2009).

2. Ik verken en verdedig deze meerduidigheidsthese, zonder haar daar zo te noemen, uitgebreid in deel 1 van Bransen (2013, pp. 33-138).

3. Zo af en toe blijft een emancipatoir ongenoegen oprispen bij de constatering dat de 
Nederlandse taal geslachtelijk niet neutraal is. Vandaar deze voetnoot, om toch maar weer te benadrukken dat ik "hij", "hem" en "zijn" zal gebruiken als ik het in abstracto over een persoon heb en liever ongeslachtelijke voornaamwoorden had willen gebruiken, omdat ik het dan over iemand heb waarvan het geslacht in feite niet ter zake doet.

4. In het voetspoor van Kahneman (2003), Evans (2003) en Strack en Deutsch (2004) hebben allerlei wetenschappers bijgedragen aan een gesofistikeerd beeld van twee min of meer onafhankelijk van elkaar opererende cognitieve processen, die we in ons alledaagse doen en laten gemakkelijk herkennen als enerzijds 'de automatische piloot' en anderzijds 'de onderzoekende houding'.

5. Vandaar dat het in onze, nog steeds moderne, cultuur een gewoonte geworden is ons tot het wetenschappelijk gezag van deskundigen te wenden zodra onze verwachtingen niet lijken te kloppen. Zie Bransen (2013).

6. De term wordt tegenwoordig niet meer gebruikt, maar de laatste vondst - Van IJzendoorn noemt de pedagogiek een "integratieve interventie-wetenschap" (Van IJzendoorn, 2002) - is niet wezenlijk anders en herbevestigt het gegeven dat de worsteling met de kloof tussen theorie en praktijk kenmerkend is voor de wetenschappelijke pedagogiek. Ik zal in het vervolg de term handelingswetenschap blijven gebruiken, en daar dan ook Van IJzendoorns variant onder scharen.

7. Statistische aggregatie van data is veel betrouwbaarder dan het oordeel van de ervaren deskundige, aldus Grove en Meehl (1996). Maar zie ook Westen en Weinberger (2004).

8. Er ontstaan alternatieven, parallel aan de praktische behoefte aan een persoonsgerichte aanpak in de zorg. Zie bijvoorbeeld Molenaar en Campbell (2009).

9. Het probleem is hier het voorkomen van de 'ecological fallacy', die gemaakt wordt als men correlaties gevonden op populatieniveau van toepassing acht op de individuele leden van de populatie. Al bekend sinds Robinson (1950).

10. Zie hierover de uitgebreide filosofische literatuur over zelfkennis. Zie bijvoorbeeld mijn bijdrage aan die discussie (Bransen, 2015).

11. Ik ben een anonieme referent van dit tijdschrift dank verschuldigd voor een aantal zeer terechte opmerkingen over de manier waarop ik mijn pleidooi aanvankelijk had geformuleerd. Dankzij hem of haar worden er in deze tekst minder (hopelijk zelfs geen) suggesties gewekt die ik uiteindelijk niet voor mijn rekening zou willen nemen.

\section{Referenties}

Abbott, B. P., Abbott, R., Abbott, T. D., Abernathy, M. R., Acernese, F., Ackley, K., ... Adya, V. B. (2016). Observation of gravitational waves from a binary black hole merger, Physical Review Letters, $116(6)$, 06112.

Baker, L. R. (1999). What is this thing called 'Commonsense Psychology'?. Philosophical Explorations, 2(1), 3-19.

Bransen, J. (2011). Nou zeg, waar bemoei je je mee. Algemeen Nederlands Tijdschrift voor Wijsbegeerte, $103(1), 4-20$.

Bransen, J. (2013). Laat je niets wijsmaken. Over de macht van experts en de kracht van gezond verstand. Zoetermeer: Klement.

Bransen, J. (2015). Self-Knowledge and Self-Love. Ethical Theory and Moral Practice, 18(2), 309-321.

Davidson, D. (1973). Radical interpretation. Dialectica, 27(1), 314-328.

Davidson, D. (1985). Incoherence and irrationality. Dialectica, 39(4), 345-354. 
Dennett, D. (1987). The Intentional Stance. Cambridge/Mass.: MIT Press.

Evans, J. (2003). In two minds: Dual-process accounts of reasoning. Trends in Cognitive Sciences, 7 (10), 454-459.

Frankfurt, H. (2006). Taking ourselves seriously \& getting it right. Stanford: Stanford University Press.

Goldberg, N. (2009). Response-dependence, noumenalism, and ontological mystery. European Journal of Philosophy, 17(4), 469-488.

Grove, W. M., \& Meehl, P. E. (1996). Comparative efficiency of informal (subjective, impressionistic) and formal (mechanical, algorithmic) prediction procedures: The clinical-statistical controversy. Psychology, Public Policy, and Law, 2(2), 293-323.

Hasselman, F. (2015). Beyond the boundary. An analysis of verisimilitude and causal ontology of scientific claims. Atiologies of developmental dyslexia as a case in point. Gepubliceerd op internet: http://fredhasselman.com/?page_id=341

Huitink, C., Vermaes, I., Engels, R., Ament, M., \& Nadorp, M. (2014). Ethiek van behandelduur in orthopedagogische centra: "Ambulantisering" zonder hard bewijs. Orthopedagogiek: Onderzoek en Praktijk, 53(5), 230-240.

Kahneman, D. (2003). A perspective on judgment and choice: Mapping bounded rationality. American Psychologist, 58(9), 697-720.

Kroonenberg, P. M. (2002). Statistiek: Argumentatiemiddel bij pedagogische vragen. In R. van IJzendoorn \& H. de Frankrijker (eds.), Pedagogiek in beeld (pp. 69-87). Houten: Bohn Stafleu van Lochum.

Molenaar, P. C. M., \& Campbell, C. G. (2009). The new person-specific paradigm in psychology. Current Directions in Psychology, 18(2), 112-117.

Mooney, K., Graziano, A., \& Katz, J. (1985). A factor analytic investigation of children's nighttime fear and coping responses. The Journal of Genetic Psychology, 146(2), 205-215.

Pettit, P. (1991). Realism and response-dependence. Mind, 1oo(4), 587-626.

Quine, W. V. O. (1992). Pursuit of truth. Cambridge/Mass.: Harvard University Press.

Richards, R. (1987). Darwin and the emergence of evolutionary theories of mind and behavior. Chicago: The University of Chicago Press.

Robinson, W. (1950). Ecological correlations and the behaviour of individuals. American Sociological Review, 15, 351-357.

Ryle, G. (1945). Knowing how and knowing that: The presidential address. Proceedings of the Aristotelian Society, 46, 1-16.

Ryle, G. (1949). The concept of mind. London: Hutchinson \& Co. Publishers.

Ter Horst, W. (1973). Beknopt overzicht van het T.D.-concept. Tijdschrift voor Orthopedagogiek, 12, 142-146.

Ter Horst, W. (1978). Proeve van een orthopedagogisch theorie-concept. Kampen: Kok.

Ter Horst, W. (1980). Algemene orthopedagogiek. Proeve van een theorie-concept. Kok: Kampen.

Ter Horst, W. (2006). Het herstel van het gewone leven, Houten: Bohn Stafleu van Loghum.

Shapiro, L. (2011). Embodied cognition. London: Routledge.

Strack, F., \& Deutsch, R. (2004). Reflective and impulsive determinants of social behavior. Personality and Social Psychology Review, 8(3), 220-247.

Van IJzendoorn, M., \& De Frankrijker, H. (2002). Pedagogiek in beeld. Een inleiding in de pedagogische studie van opvoeding, vorming en hulpverlening. Houten: Bohn Stafleu Van Lochum.

Varela, F., Thompson, E., \& Rosch, E. (1991). The embodied mind: Cognitive science and human experience. Cambridge/Mass.: MIT Press.

Velleman, J. D. (2009). How we get along. Cambridge: Cambridge University Press.

Westen, D., \& Weinberger, J. (2004). When clinical description becomes statistical prediction. American Psychologist, 7, 595-613. 
PEDAGOGIEK

Williams, B. (1981). Moral luck: Philosophical papers. Cambridge: Cambridge University Press.

Wood, A. (2003). The good will. Philosophical Topics, 31(1/2), 457-484.

\section{Over de auteur}

Jan Bransen is werkzaam als hoogleraar Filosofie van de gedragswetenschappen aan de Radboud Universiteit Nijmegen.

Correspondentieadres: j.bransen@pwo.ru.nl 